\title{
EXPERIMENTAL AND NUMERICAL INVESTIGATIONS ON THE AUTOMOTIVE RADIATOR PERFORMANCE USING LOUVERED-FIN HEAT EXCHANGER
}

\section{Mohamed El- sayed Gomaa}

Specialized Studies Academy, Workers University, Technology Dept., Ismailia, EGYPT.

Email: msgomaas@hotmail.com

(Received January 26, 2009 Accepted March,2, 2009)

In the present work, experimental and numerical investigations have been performed to determine the performance of an automotive radiator using louvered-fin geometry with reference to flat-fin geometry. Four radiators specimens were designed and manufactured, three specimens with different louvered fin per inch and the other with flat fin. The experimental work was carried out on a four cylinders petrol engine (Seat-124A).The effects of engine speed, number of fins per inch (FPI), Reynolds number and radiator boundary conditions on the radiator performance were investigated at a certain louvered angle of $25^{\circ}$. The specific fuel consumption was also investigated experimentally. Numerical CFD investigation using finite volume discretization method was also conducted to predict the radiator performance extensively. The momentum and energy equations were solved by the second order up wind scheme. The air flow and heat transfer through the louvered fin passage were treated using the $k-\varepsilon R N G$ turbulence model. For the validation of the numerical model, the numerical results were compared with corresponding experimental data. It was noticed that the level of the turbulence increases through the transition region of the louvered flowpassage which will lead to a disturbance of the boundary layer thickness and hence, the increase in the heat transfer coefficient was achieved.. The results indicated that an improvement of about $23 \%$ in the Nusselt number and a decrease of about $19 \%$ in the specific fuel consumption at full load could be achieved due to using louvered-fin geometry compared to flat-fin geometry at the same operating conditions.

KEYWORDS: Engine cooling system, automotive radiators, Louvered fins.

\section{NOMENCLATURE}

$\begin{array}{llll}\mathrm{A}_{\mathrm{o}} & \text { heat transfer surface area }=A_{f} & \mathrm{C}_{\mathrm{p}} & \text { specific heat, } \mathrm{J} / \mathrm{kg} . \mathrm{K} \\ & +A_{t}, \mathrm{~m}^{2} & \mathrm{D}_{\mathrm{h}} & \text { hydraulic diameter, } \mathrm{m} \\ \mathrm{A}_{\mathrm{f}} & \text { surface area of the fins, } \mathrm{m}^{2} & \mathrm{f} & \text { friction factor } \\ \mathrm{A}_{\mathrm{ff}} & \text { free flow area, } \mathrm{m}^{2} & \mathrm{~h} & \text { heat transfer coefficient, } \\ \mathrm{A}_{\mathrm{fr}} & \text { frontal area, } \mathrm{m}^{2} & & \mathrm{~W} / \mathrm{m}^{2} . \mathrm{K}\end{array}$




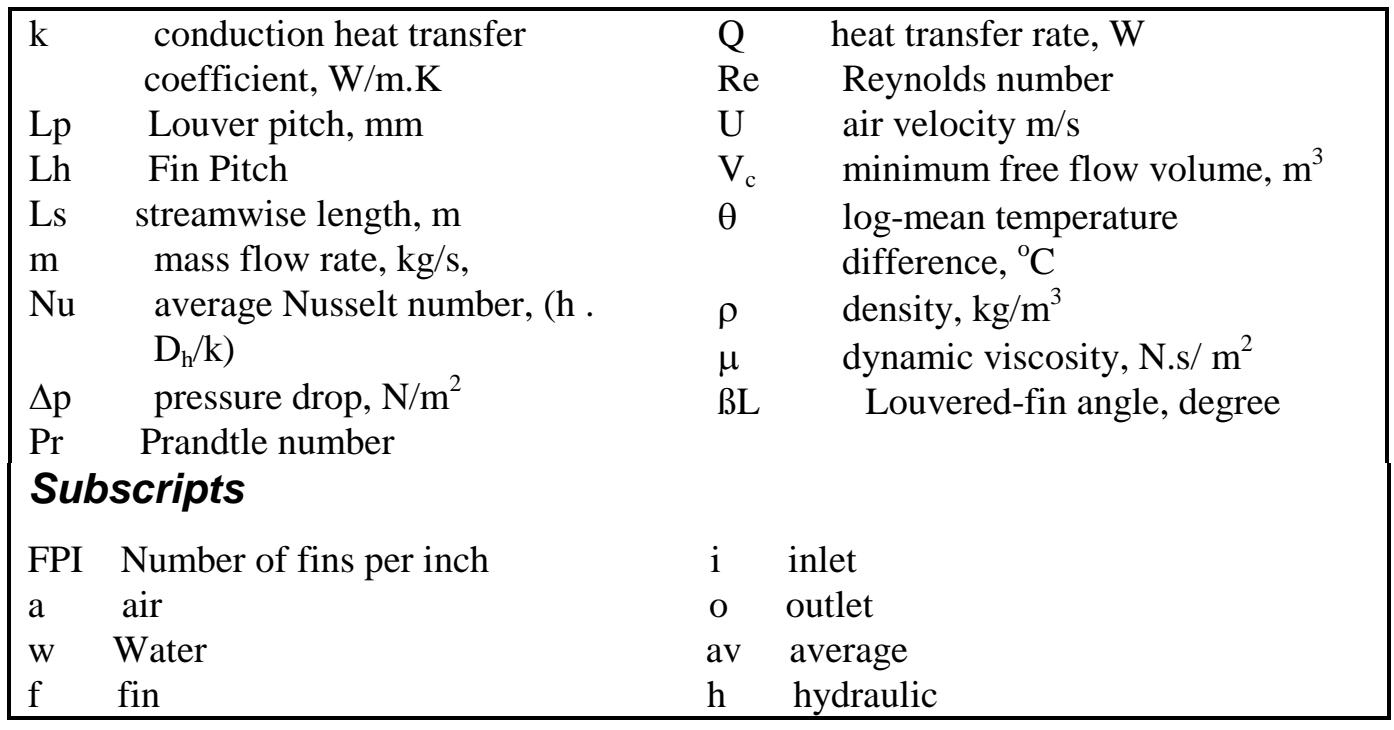

\section{INTRODUCTION}

Cairo, the capital city of Egypt, is one of the highest traffic density cities in the world, this leads to an increase in automotive engines temperature. Therefore, improving the engine cooling system at all operating conditions becomes an essential task. The need for more efficient cooling system of the automotive engine requires an understanding of the performance characteristics of system components. One of the key components is the automotive radiator, which is considered here. Water cooling system is commonly used in automotive engines to maintain a stable thermal state within the entire range of load and speed. In closed water circulation system using a radiator, water is forced through the jacket of cylinder block and the cylinder head by a circulating pump as shown in Fig.1. The hot water leaving the engine enters the radiator. Water flows through tubes provided with external fins. A fan driven by the engine sucks air over the finned tubes and reduces the temperature of the water passing through them. The cooled water leaving the radiator enters the circulating water pump. It is well known, both theoretically and experimentally, that flow rate and temperature of the air in front of radiator have a strong influence on the heat dissipation capacity of the radiator and on the cooling system. The dominant thermal resistance in radiator occurs on the airside. Therefore, the air flow is an essential factor affecting the engine cooling system performance. To improve the cooling system performance without unduly reducing the power output of the engine, passive enhancement techniques are often employed using louvered-fin geometries. Flat tube louvered-fins are used in many compact heat exchanger applications to enhance the air-side heat transfer performance. Louvers reduce the average thermal boundary-layer thickness by interrupting its growth and by enhancing mixing through large-scale instabilities, hence increasing the average heat transfer coefficient. There have been a number of studies on the thermal-hydraulic characteristics of the louvered-fin -andtube heat exchangers. Beauvais [1] was the first to conduct flow visualization 
experiments on the louvered fin array. He demonstrated that louvers, rather than acting as surface roughness that enhanced heat transfer performance, acted to realign the airflow in the direction parallel to themselves. Davenport [2] performed flow visualization experiments identical to those of Beauvais and further demonstrated two flow regimes, duct directed flow, and louver directed flow. In general, the flow direction follows the path of least hydraulic resistance. Under certain conditions, one of them being low Reynolds number, the flow has a propensity to move straight through between fins, rather than align itself to the louvers. At low Reynolds numbers, this is a result of the high flow resistance between louvers brought about by the thick boundary layers. Lin et al. [3] presented an interesting study of specific dissipation sensibility to radiator boundary conditions (air and coolant inlet temperatures and mass flows). Their conclusions were assessed by numerical and experimental work. Juger and Crook [4] reported an experimental testing on two radiators of the same flow area but with the tubes in vertical or horizontal position, therefore studying the influence of tube length vs. number of parallel tubes. They carried out this analysis for three different coolant fluids. Gollin and Bjork [5] experimentally compared the performance of five commercial radiators working with water and five aqueous glycol mixtures. Chen et al. [6] experimentally analyzed a sample radiator and developed regression equations of heat dissipation rate, coolant pressure drop and air pressure drop in function of the boundary conditions. Heat transfer and pressure drop performance studies by Achaichia and Cowell [7] confirmed the theory by Davenport [2] who suggested that two types of flow conditions existed depending on Reynolds number based on louver pitch. Davenport reasoned that at low Reynolds numbers, the louver boundary layers were so thick that flow between the louver gaps was essentially blocked such that the flow became axially directed or also known as duct directed. Achaichia and Cowell in fact found the flow to travel axially for a $\operatorname{Re}<40$. The numerical heat transfer predictions of Achaichia and Cowell showed that at these low Reynolds numbers, the average heat transfer coefficients approached that of duct type flows. At the intermediate Reynolds numbers there is still some disagreement as to when the flow is louver or duct directed as illustrated when comparing the numerical predictions presented by Achaichia and Cowell [7] to those estimated through flow visualization studies conducted by Webb and Trauger [8]. Performance evaluation of a radiator mounted on a turbo-charged Diesel engine has been made with and without fouling factot by Ganga Charyulu et al.[9] . The study also examines the effect of different material of construction of fins and tubes. Olsson and Sunden [10] experimentally analyzed thermal and hydraulic performance of ten real radiator tubes in the same Reynolds number. The tubes tested are one smooth tube, two ribroughened tubes, five dimpled tubes and two offset strip fin tubes. The rib-roughened tubes showed the best performance. Zhang and Tafti [11] numerically studied the effect of Reynolds number, fin pitch, louver thickness and louver angle on flow efficiency in multi-louvered fins. Results show that flow efficiency is strongly dependent on geometrical parameters. Tafti and Cui [12] presented three-dimensional simulations of four louver-tube junction geometries to investigate the louver and tube friction and heat transfer characteristics. Olit et al [13] presented a numerical analysis of a set of parametric studies (air mass flow, liquid coolant flow, fin pitch, and louver 
angle) performed on automotive radiators by a detailed rating and design heat exchanger model developed by the authors. The influence of those parameters on the full thermal and hydraulic behavior of the heat exchanger was analyzed. Numerical investigations of the louvered fin array have been performed recently by Atkinson et al. [14], Yuan et al.[15], Zhang and Tafti [16] and Tafti et al. [17] and Perrotin and Clodic [18].

Head Cylinders

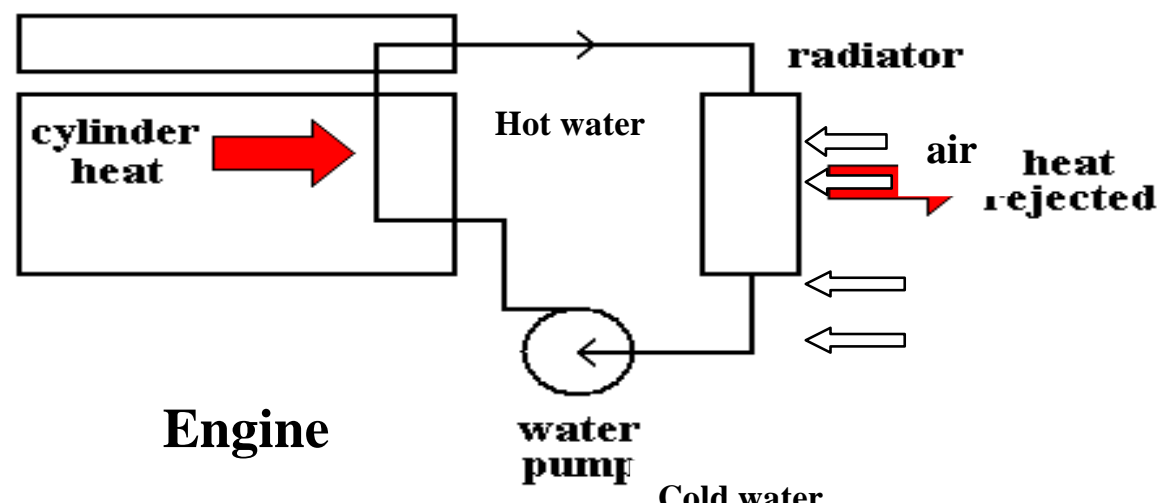

Fig.1 Automotive engine cooling system

In the present work, experimental and numerical investigations have been performed to determine the performance evaluation of an automotive radiator using flat-tube louvered-fin. The specific fuel consumption is also investigated experimentally at full load for different radiators. Four radiators specimens are designed and manufactured, three specimens with different louvered fin per inch and the other with flat fin. The effect of Reynolds number, number of fins per pitch (FPI) and radiator boundary conditions are investigated. Numerical CFD investigation using finite volume discretization method was also conducted to predict the radiator performance extensively. The purpose is to achieve a numerical solution that can offer a powerful insight into the performance characteristics of the automotive radiator on a scale and level of details not always possible with conventional experimental methods. For the validation, the numerical results are compared with existing experimental data.

\section{EXPERIMENTAL TEST RIG}

A schematic diagram of the experimental apparatus is shown in Fig.2. The experimental work was carried out on a Seat 124A (1.20 litres), $50 \mathrm{~kW}$ maximum power at $5200 \mathrm{rpm}$, water cooled, four cylinders, 4-strok petrol engine. Four radiators test specimens were prepared. Air flow is driven by the cooling fan through a rectangular parallelepiped duct $(400 \times 500 \times 2000 \mathrm{~mm})$ where the test radiator with its cooling fan is placed. Geometry of the louvered-fin radiator is shown in Fig.3 and Fig.4.The engine was loaded by a heenan type hydraulic dynamometer. A speed sensor was attached to the engine crankshaft to measure its speed. Testo 415 thermal anemometer was used to measure the air velocity. A definite number of pre-calibrated 
$K$-type thermocouples of $0.3 \mathrm{~mm}$ wire diameter, of $1 \mathrm{~mm}$ probe diameter and of $20 \mathrm{~ms}$ response time, $[19,20]$ were used to measure the coolant inlet and outlet temperatures. Two thermocouples were used to measure the surrounding air temperature, and other eight ones were used to measure the air outlet temperature from the fin passage as shown in Fig.5. The average temperature of air outlet from the fin passage is the sum of the readings of the eight thermocouples located at direction of air outlet divided by eight. Two thermocouples measure the water inlet temperature in the radiator and other two ones measure the water outlet temperature from the engine. The air pressure drop before the radiator and after the radiator in the air duct was measured by an orifice flow meter fitted via a straight pipe of $26.15 \mathrm{~mm}$ diameter. The orifice plate was designed and manufactured according to the BSI catalogue data, [21]. The differential pressure head through the orifice was recorded by using a digital micro manometer having a resolution of $0.01 \mathrm{~mm}$ water. The experimental test rig was provided with a PC, a data acquisition system and the necessary attachments to measure and record the temperatures at a sample time of $2 s$, via multi I/O digital card. A PC-based data acquisition system utilizing PLC-818PG and a data logger was used for data collection and monitoring. The thermocouples were connected to a data acquisition system through two multiplexers (multiplexer 4051) via buffers and amplifiers. A Q-Basic language software program was prepared to control the data collection and monitoring. This package gives a resolution of $0.01{ }^{\circ} \mathrm{C}$ for temperature measurement.

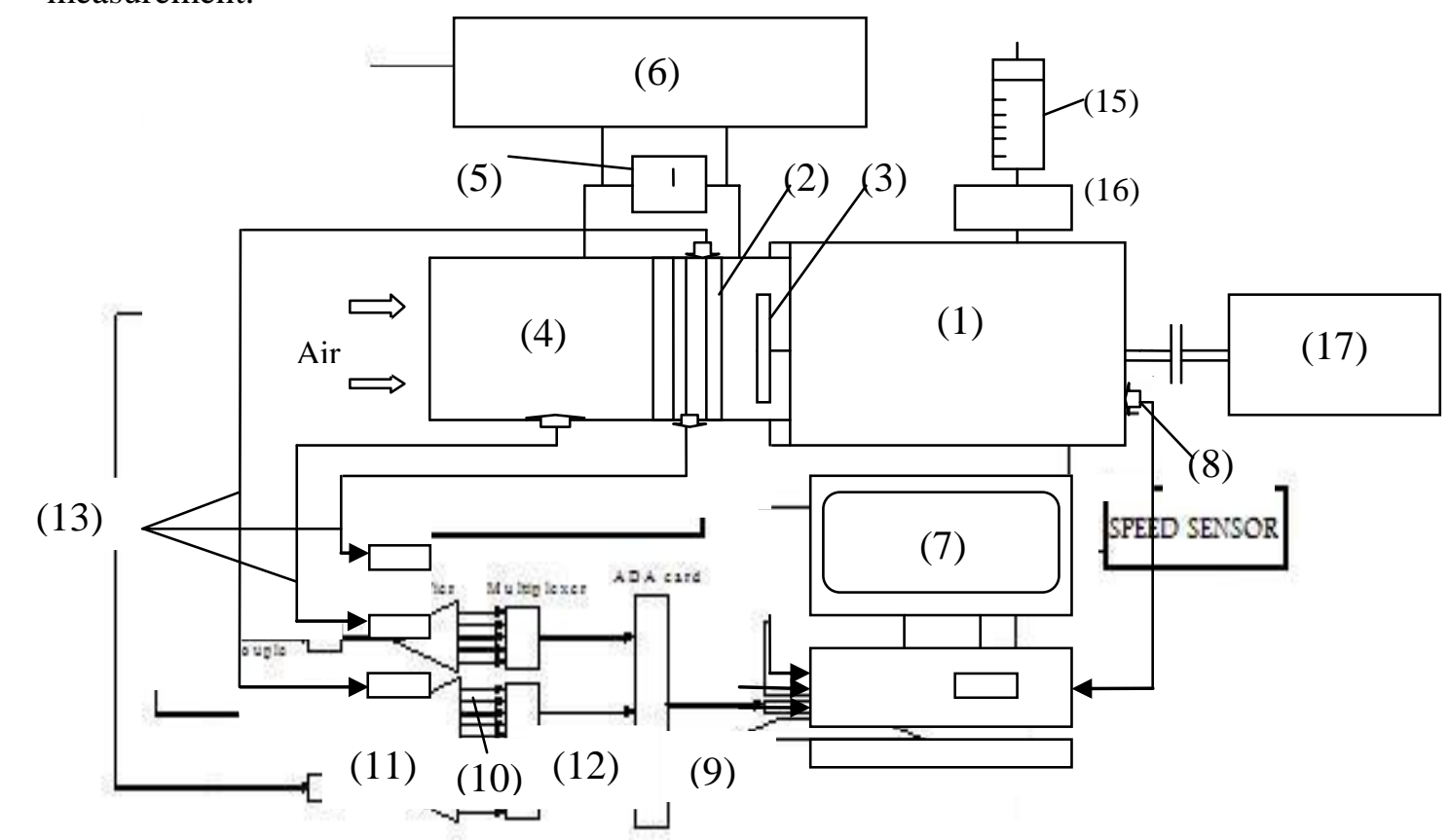

1. Petrol engine (Seat- 124), 2. Radiator, 3. Cooling fan, 4. Air duct, 5. Orifice, 6. Digital manometer, 7. PC Computer, 8. Speed sensor, 9. Data acquisition card, 10. Amplifiers, 11. Buffers, 12.Multiplexers, 13. Thermocouples, 14. Petrol fuel tank, 15. $50 \mathrm{~mL}$ graduated burette 16. Carburetor, 17. Hydraulic dynamometer.

Fig.2 Schematic diagram of the test rig 


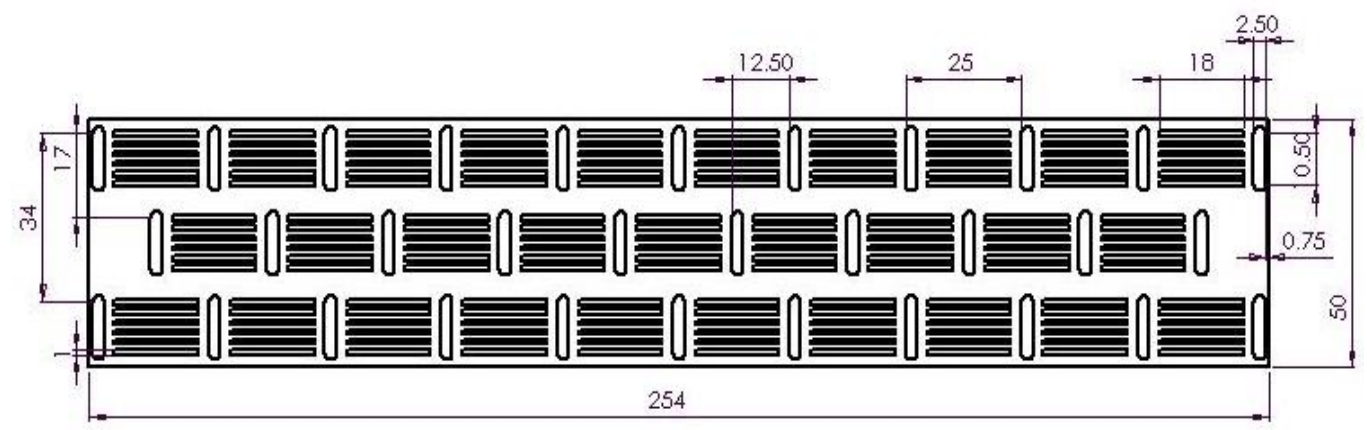

Fig.3: Geometry of the louvered-fin radiator

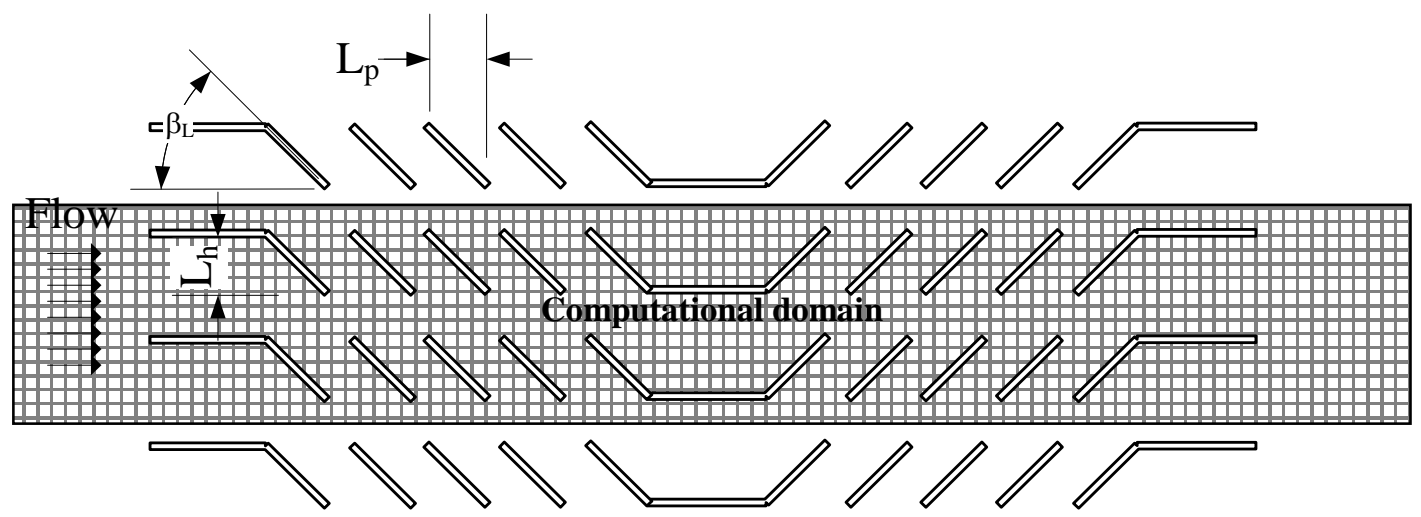

Fig.4: Louvered fin passage

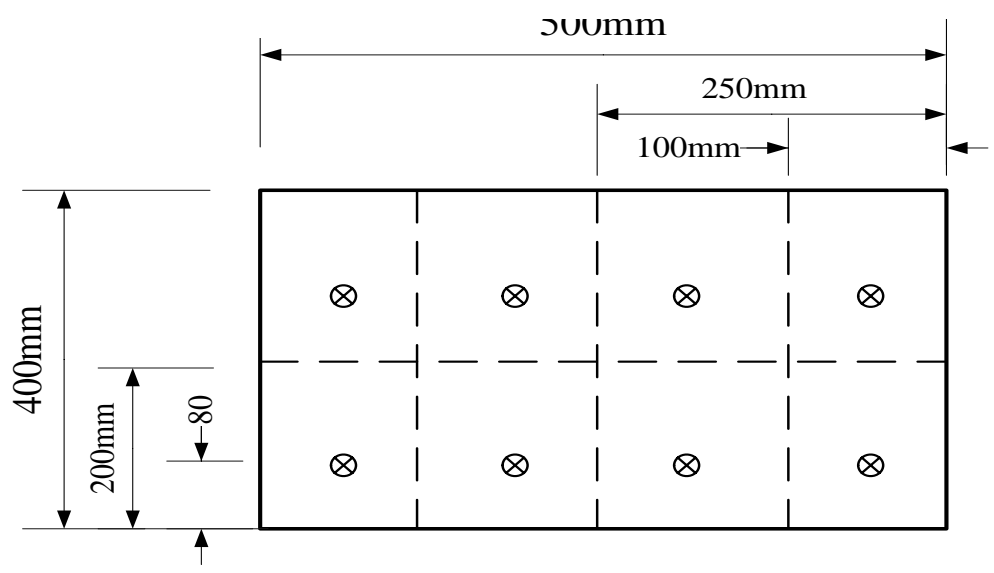

Fig. 5 Thermocouple probe locations through the duct cross-section

The fuel flow rate was measured through measuring the time required for consuming $50 \mathrm{~mL}$. The graduated burette provides petrol fuel for the engine, and it's refilled from the main petrol fuel tank before each experiment. The time needed for the consumption of $50 \mathrm{~mL}$ of the petrol fuel was measured using a stop watch. Specific fuel consumption was the measure of fuel flow rate per unit power output. 


\section{TEST PROCEDURE}

In the current experimental work, four sets of experiments were carried out. The purpose of these experiments was to assess the following tasks:

1. The first set of experiments in this study starts by a basic automotive radiator of flat-fin to determine performance of the traditional radiator. The results obtained will be used as a basis data for comparison with that obtained from the other three louvered-fin radiators.

2. The second set of experiments was used to study the effect of using three different louvered fins radiators respectively on performance of the cooling system of the engine at different speeds.

3. The third set of experiments was used to study the specific fuel consumption in the engine as function of engine speed for both flat fin and louvered fin with 10 FPI radiators.

4. The last set of experiments was used to validate the numerical results.

The experimental results were carried out using a combination of eight different engine speeds and different FPI, as illustrated in Table (1).

$\underline{\text { Table (1) Experimental conditions }}$

\begin{tabular}{|l|c|}
\hline Engine speed (RPM) at full load. & $500,1000,1500,2000,2500,3000,3500,4000$ \\
\hline Number of Flat fin per inch & 10 FPI \\
\hline Number of louvered fin per inch & 8 FPI, 10 FPI, 12 FPI \\
\hline
\end{tabular}

To insure high accuracy of the measured values, each reading was repeated three times and mean of the three measured values was calculated.

The mean air velocity was measured experimentally at six engine speeds as shown in table (2).

Table (2), values of average air velocities at different engine speeds

\begin{tabular}{|c|c|c|c|c|c|c|}
\hline Engine speed, rpm & 1500 & 2000 & 2500 & 3000 & 3500 & 4000 \\
\hline Mean air velocity, $\mathrm{m} / \mathrm{s}$ & 3.5 & 5.11 & 5.9 & 7.5 & 8 & 9.3 \\
\hline
\end{tabular}

\section{COMPUTATIONAL DETAILS}

A finite volume discretization method using non-orthogonal body-fitted coordinates with the SIMPLE solution algorithm was applied. Convection and diffusions term of momentum and energy equations were approximated by the second order upwind scheme. The base geometry of louvered-fin radiator passage is shown in Fig. 4. A grid dependence check was performed in order to maintain reasonable accuracy at moderate CPU time. A multi-blocks mapped mesh technique was applied for the mesh generation of both flat and louvered fin model with the grid size of $0.1 \mathrm{~mm}$ as shown in Fig. 6. The values of the residuals convergence criteria were less than $10^{-4}$ for all runs. 


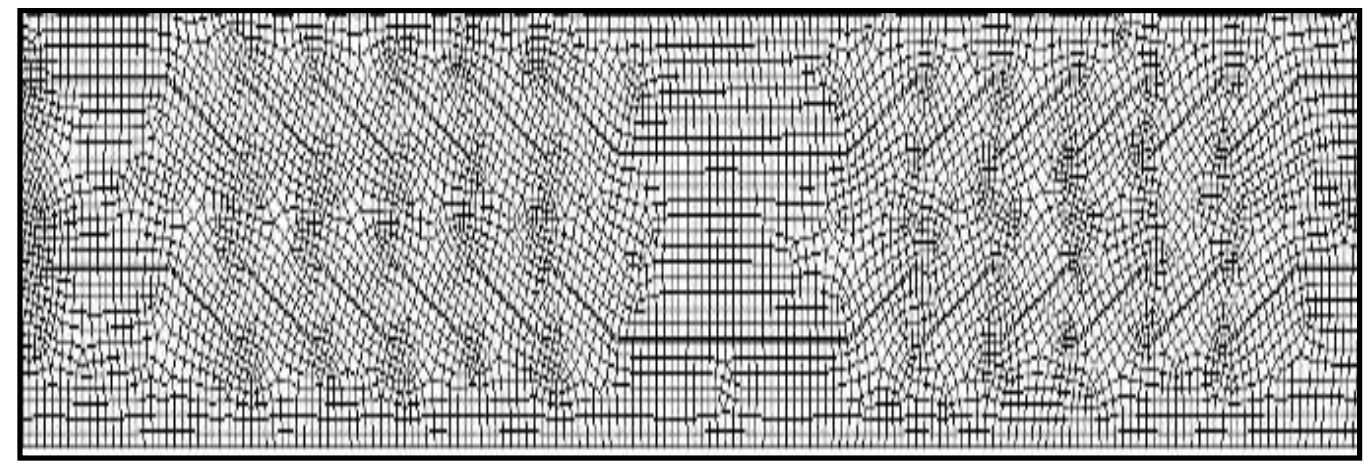

Fig. 6 Grid distribution of louvered-fin automotive radiator numerical model

\section{GOVERNING EQUATIONS}

The dimensionless governing equations of continuity, momentum, energy and the heat conduction through finned tube radiator can be written as:

$$
\begin{aligned}
& \nabla u^{*}=0 \\
& \left(u^{*} \cdot \nabla\right) u^{*}=-\nabla P^{*}+\left(\frac{1}{\operatorname{Re}}\right) \nabla^{2} u^{*} \\
& \left(u^{*} \cdot \nabla\right) T^{*}=\left(\frac{1}{\operatorname{Re} P r}\right) \nabla^{2} T^{*} \\
& \nabla^{2} T_{\text {fin }}^{*}=0 \\
& \text { Where; } \quad x^{*}=\frac{x}{D_{h}}, \quad u^{*}=\frac{u}{u_{i}}, \quad P^{*}=\frac{p-p_{o}}{\rho u_{i}^{2}}, \quad T^{*}=\frac{T-T_{w}}{T_{w}-T_{i}}
\end{aligned}
$$

\section{BOUNDARY CONDITIONS}

The boundary conditions are sufficiently important to warrant a detailed description of the computational domains. The numerical solution of the air flow through the louvered fin array was treated as steady, incompressible, two dimensional with neglecting the buoyancy force. The hatched area in Fig.4 designates the computational domain, where symmetry conditions were specified on the mid-plane of two successive rows of the louvered fins. The symmetries presented in the problem allow the computational time to be reduced. At the upstream boundary that located three times of the flat-tube transverse pitch, a uniform flow velocity is specified. At the downstream (exit) boundary that located six times of the flat-tube transverse pitch, the pressure is set to zero. At the symmetry planes, all normal components and gradients are set to zero. While at the solid surfaces, no-slip conditions and constant heat flux are specified. 


\section{METHOD OF CALCULATION}

The log-mean temperature difference method (LMTD) of calculation is applied where the hot and cold fluid temperatures are known. The air and the hot water properties are evaluated at the fluid bulk temperature.

The rate of heat transfer on the airside is defined as:

$$
Q_{a}=m_{a} C p_{a} \Delta T_{a}
$$

The rate of heat transfer on the waterside is defined as:

$$
Q_{w}=m_{w} C p_{w} \Delta T_{w}
$$

Due to uncertainty in measurements and heat losses from the test rig, the rate of heat transfer in airside is not equal to the rate of heat transfer in waterside. For this purpose, the total heat transfer rate used in calculation is the mathematical average of the airside and waterside heat transfer rate, [22], and it is defined as:

$$
Q_{a v}=\frac{Q_{w}+Q_{a}}{2}
$$

The heat transfer balance is defined as:

$$
\begin{aligned}
& Q_{a v}=A_{o} U_{o} \theta_{m} \\
& \theta_{m}=\frac{\left(T_{a o}-T_{w i}\right)-\left(T_{a i}-T_{w o}\right)}{\ln \frac{\left(T_{a o}-T_{w i}\right)}{\left(T_{a i}-T_{w o}\right)}}
\end{aligned}
$$

The overall heat transfer thermal resistance is defined as;

$$
\frac{1}{A_{o} U_{o}}=\frac{1}{A_{o} h_{o}}+\frac{\ln \left(D_{o} / D_{i}\right)}{2 \pi l k}+\frac{1}{A_{i} h_{i}}
$$

The heat transfer coefficient on the water side, $h_{i}$ is calculated from the Gnielinski semi-empirical correlation, [23]:

$$
\begin{aligned}
& h_{i}=\left(\frac{k}{D_{i}}\right) \frac{\left(\operatorname{Re}_{D i}-1000\right) \operatorname{Pr}\left(f_{i} / 8\right)}{1+12.7 \sqrt{f_{i} / 8}\left(\operatorname{Pr}^{2 / 3}-1\right)}, \\
& 3000 \leq \operatorname{Re}_{\mathrm{Di}} \leq 5 \times 10^{6} \\
& f_{i}=\left(0.79 \ln \left(\operatorname{Re}_{D i}\right)-1.64\right)^{-2}
\end{aligned}
$$

The Reynolds number on the air side is defined as:

$$
\operatorname{Re}=\frac{u_{\max } D_{h}}{v}
$$

$D_{h}=$ the hydraulic diameter of the heat exchanger and it is defined as:

$$
D_{h}=\frac{4 A_{f f} L_{s}}{A_{o}}
$$

The Nusselt number is defined as:

$$
N u=\frac{h_{o} D_{h}}{k}
$$


The friction factor is defined according to [24] as:

$$
f=\frac{A_{f f} \rho_{m}}{A_{o} \rho_{i}}\left[\frac{2 \Delta P \rho_{i}}{G^{2}}-\left(1+\sigma^{2}\right)\left(\frac{\rho_{i}}{\rho_{o}}-1\right)\right]
$$

Where:

$$
u_{\max }=\frac{u}{\sigma}, \quad \rho_{m}=\frac{\rho_{i}+\rho_{o}}{2}, \quad \sigma=A_{f f} / A_{f r}, \quad G=\frac{\rho u}{\sigma}
$$

The outlet temperature of the model, $T_{o}$ and inlet pressure $P_{i}$ are computed numerically as:

$$
T_{o}=\frac{\int T \rho \vec{u} \cdot d \vec{A}}{\int \rho \vec{u} \cdot d \vec{A}}, \quad P_{i}=\frac{\int P \rho \vec{u} \cdot d \vec{A}}{\int \rho \vec{u} \cdot d \vec{A}}
$$

\section{RESULTS AND DISCUSSION}

The results obtained in this study are divided in three parts: (i) experimental results, (ii) experimental validation of numerical results and (iii) numerical results.

\section{EXPERIMENTAL RESULTS}

Figure 7 implies that, the heat transfer coefficient increases with increasing the engine speed at full load for different fins. This is due to the increase in the velocity of air which raises the heat transfer coefficient. At certain engine speed, the use of louvered fin geometry leads to an enhancement in the heat transfer coefficient when compared with flat-fin geometry.

The variation of cooling rate versus the engine speed at different louvered-fins spacing is shown in Fig.8. The figure shows that, the increase in the engine speed leads to an increase in the rate of cooling due to the increase in fan speed and the temperature difference between water and air. Also, the increase in the number of fin per inch leads to an increase in the rate of cooling at certain engine speed.

The Nusselt number was plotted versus Reynolds Number at different louvered- fins per inch as illustrated in Fig.9. The figure shows that, the increase in the Reynolds number leads to an increase in Nusselt number; this is due to the increase in the velocity of air which raises the heat transfer coefficient. It is noticed that an improvement of about $23 \%$ in the Nusselt number could be achieved due to using louvered-fin (10 FPI ) compared to the radiator using flat fin (10 FPI) at the same operating conditions.

The pressure drop variation across the radiator versus the engine speed at different louvered-fins is given in Fig.10. At certain engine speed, the use of louvered fin geometry leads to an increase in the pressure drop when compared with flat-fin geometry.

Figure11 shows that the heat transfer coefficient increases with the increase in number of louvered fin per inch at different engine speeds.

Figure 12 shows also that the rate of cooling increases with the increase in number of louvered fin per inch at different engine speeds. The increase of number of fin per inch enhances the rate of cooling due to its increase of transfer surface area. 


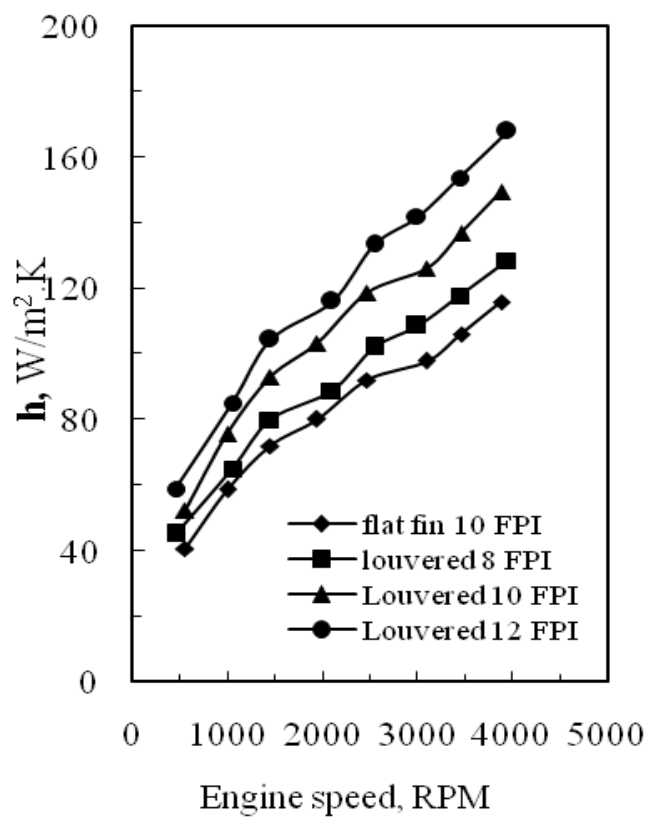

Fig.7 Variation of the heat transfer Coefficient versus the engine speed

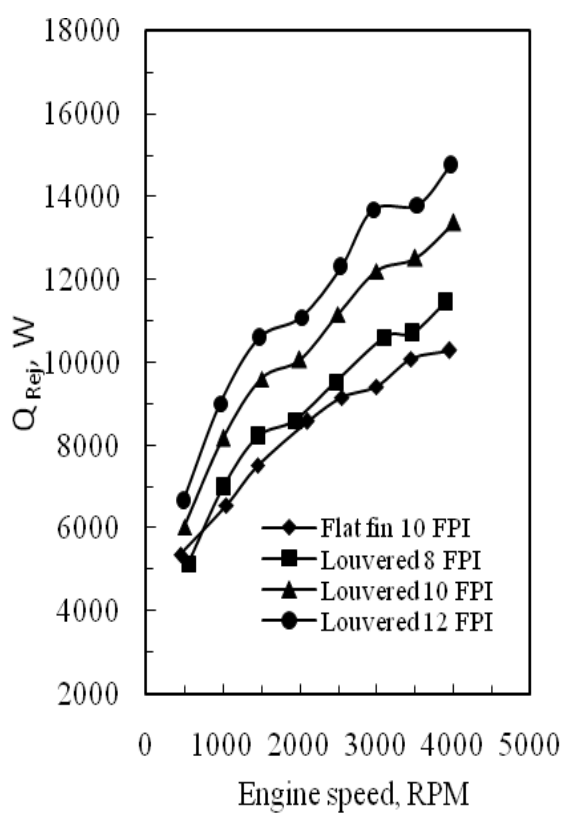

Fig.8 Variation of the rate of cooling versus the engine speed

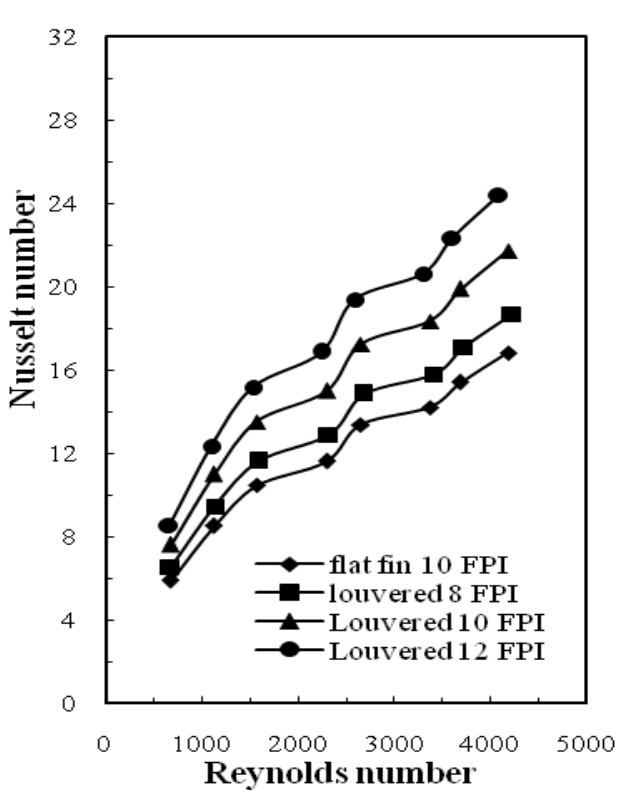

Fig.9 Variation of the Nusselt number versus the Reynolds number

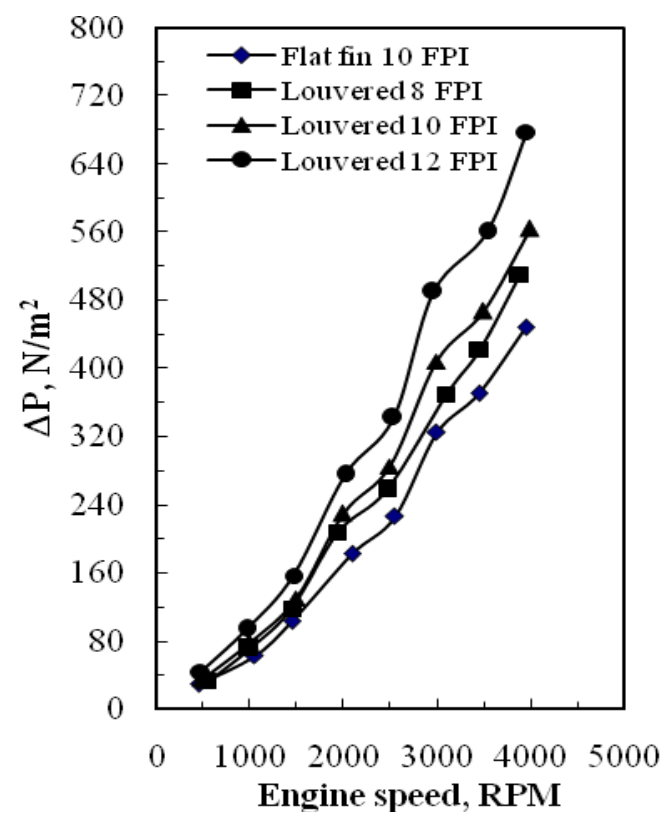

Fig.10 Variation of the pressure drop versus the engine speed 


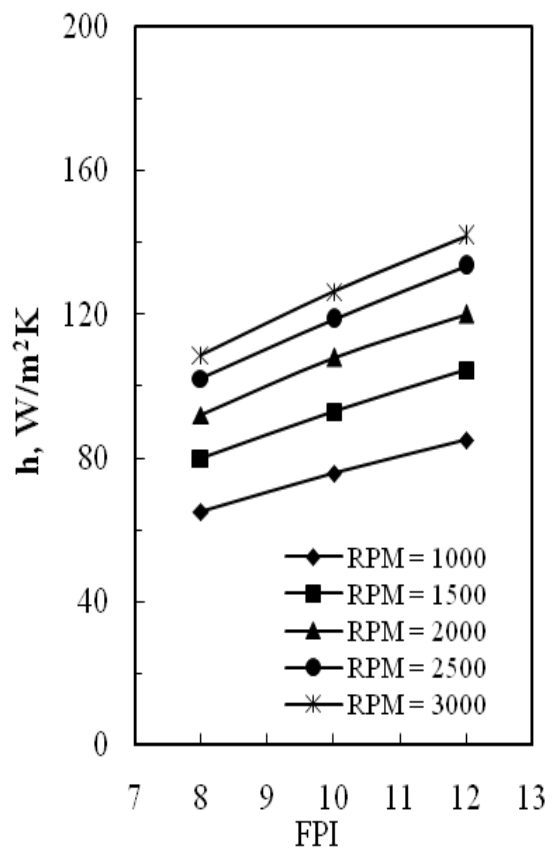

Fig.11 Variation of the heat transfer coefficient versus the number of fins per inch, FPI

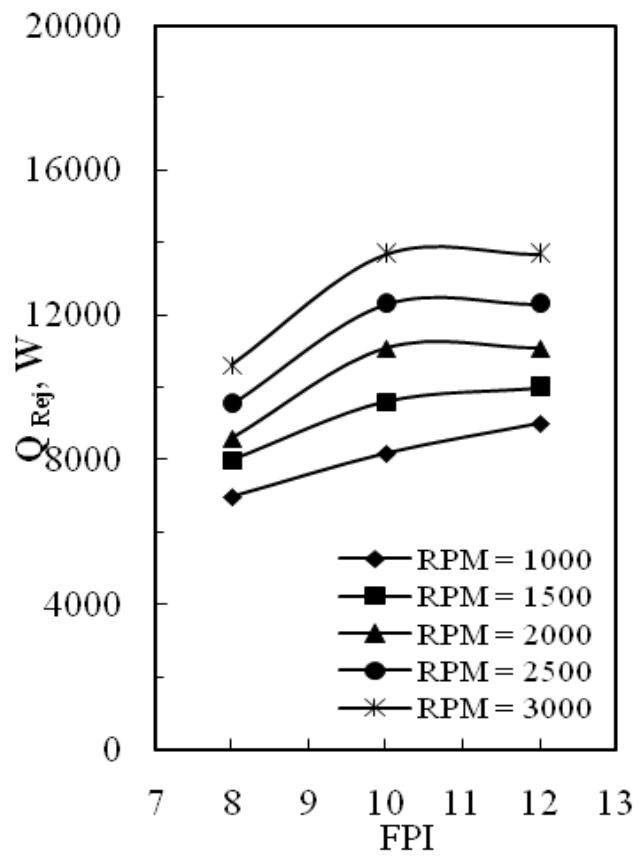

Fig.12 Variation of the rate of cooling versus the number of fins per inch, FPI

The pressure drop variation across the radiator versus different louvered-fins per inch at different engine speeds is shown in Fig.13. The figure shows that, the increase in the number of louvered fin per inch leads to an increase in the pressure drop at different engine speeds. The higher pressure loss of louvered fins yields to reduced air flows. Smaller fin spacing implies higher heat transfer capacity and air pressure drop at fixed air flow rate.

Figure 14 shows the friction factor variation across the radiator versus Reynolds number at different FPI. The figure shows that the friction factor decreases with the increase in the Reynolds number. The friction factor across the radiator using flat fin is lower than that across the radiator using louvered-fin.

Figure15 provides the variation of the specific fuel consumption in the engine versus different engine speeds at full load for both flat fin and louvered fin with 10 FPI radiators. A decrease of about $19 \%$ in the specific fuel consumption at full load in the engine could be achieved due to using louvered-fin compared to the case of radiator using flat fine at the same operating conditions. 


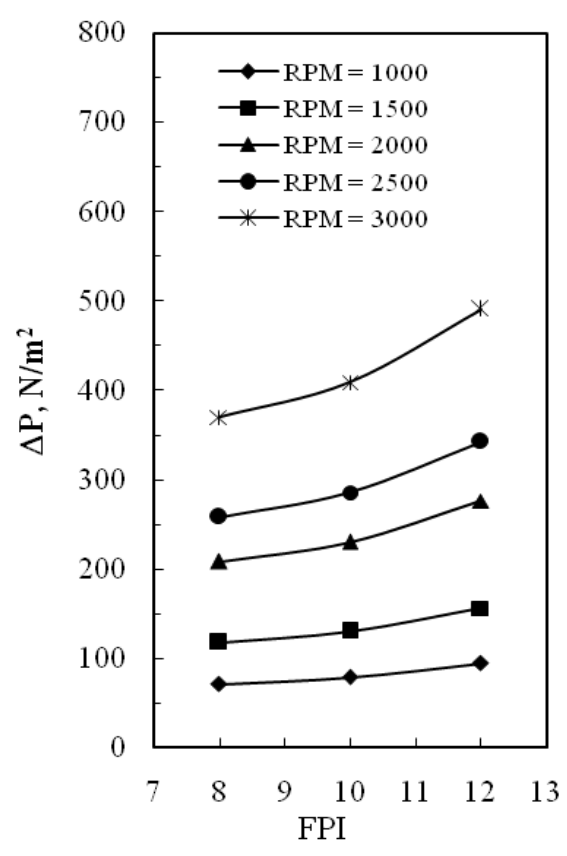

Fig.13 Variation of the pressure drop versus the number of fins per inch

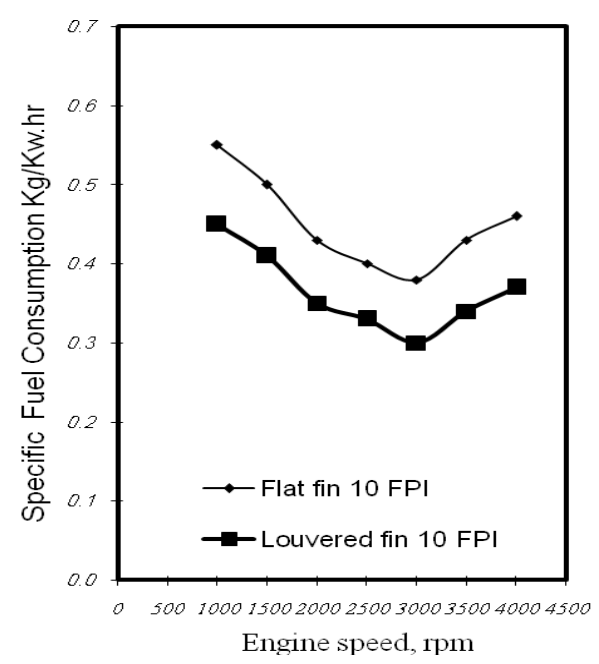

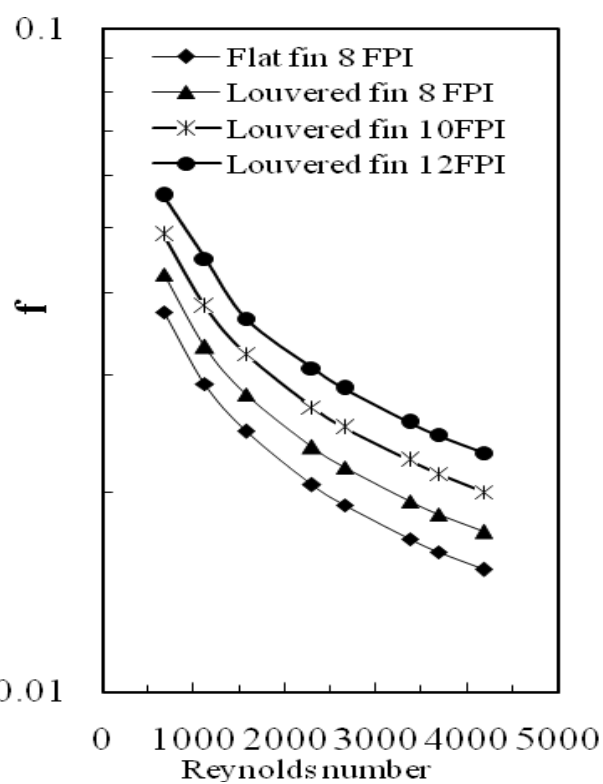

Fig.14 Variation of the friction factor versus the Reynolds number of both flat fin and louvered fin geometries

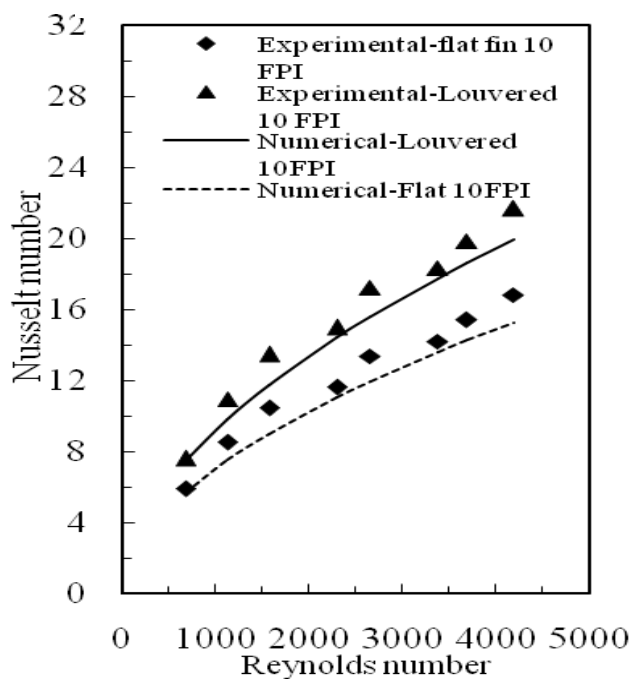

Fig.15 Variation of the specific fuel consumption Fig.16 Experimental-Numeric alcomparison versus the engine speed for both flat fin and of Nusselt number versus Reynolds number louvered fin with 10 FPI at full load. for both flat fin and louvered fin with 10 FPI

\section{NUMERICAL RESULTS VALIDATION}

Figure 16 shows the numerical model results validation of the Nusselt number with the experimental results for both flat and louvered-fin configuration. It is noticed that a 
fair agreement between the present numerical and experimental results is presented with a maximum deviations of about $\pm 13 \%$. This deviation is referred to the uncertainties in measuring instruments and the circumambient of the experiments.

\section{NUMERICAL RESULTS}

The solution of the governing equations allows us to deduce grid distribution of louvered-fin automotive radiator numerical model and vector plot of velocity magnitude of air at air velocity $8 \mathrm{~m} / \mathrm{s}$ corresponding to $\mathrm{Re}=3690$. The twodimensional of pressure, velocity and temperature distributions in Louvered-fin passage are also deduced.

Figure 17 shows the local pressure distribution through the louvered-fin passage with louvered-angle of $25^{\circ}$. It is noticed that the louvered-fin passage geometry affects the pressure drop positively.

The global velocity distribution across the louvered fin passage is essential for understanding of the local flow and heat transfer phenomena. Figure 18 shows the local velocity distribution of the louvered-fin angle of $25^{\circ}$. The airflow is strongly accelerated in the passages between two successive passages. In general, velocity magnitudes are slower near the top of passage than at the bottom of the passage. It is clear that the louvered-fin configuration increases the level of turbulence through the fin flow-passage which enhances the heat transfer coefficient, however higher pressure drop is expected when compared with the flat-fin passage.

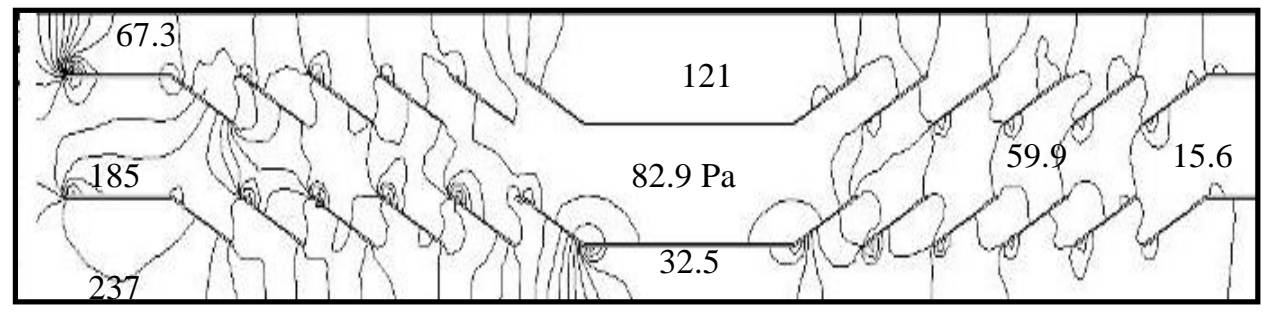

Fig. 17 Pressure contours of air for the CFD model at air velocity $8 \mathrm{~m} / \mathrm{s}$

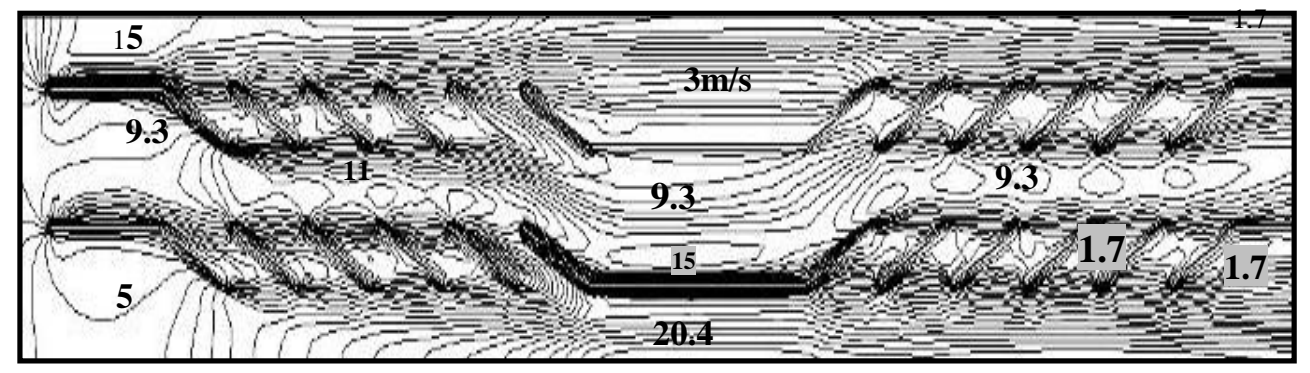

Fig.18 Contours of velocity Magnitude $(\mathrm{m} / \mathrm{s})$

Figure 19 shows the details of the vector plot of the velocity distribution at the 10 FPI of the louvered fin-passage. This figure shows that the level of the turbulence increases through the transition region of the flow-passage which will lead to a 
disturbance of the boundary layer thickness and hence, increase in the heat transfer coefficient is achieved.

Temperature contours have lower values in the immediate vicinity of the louvered fin passage on the top lower surface than on the bottom surface as shown in Fig.20.

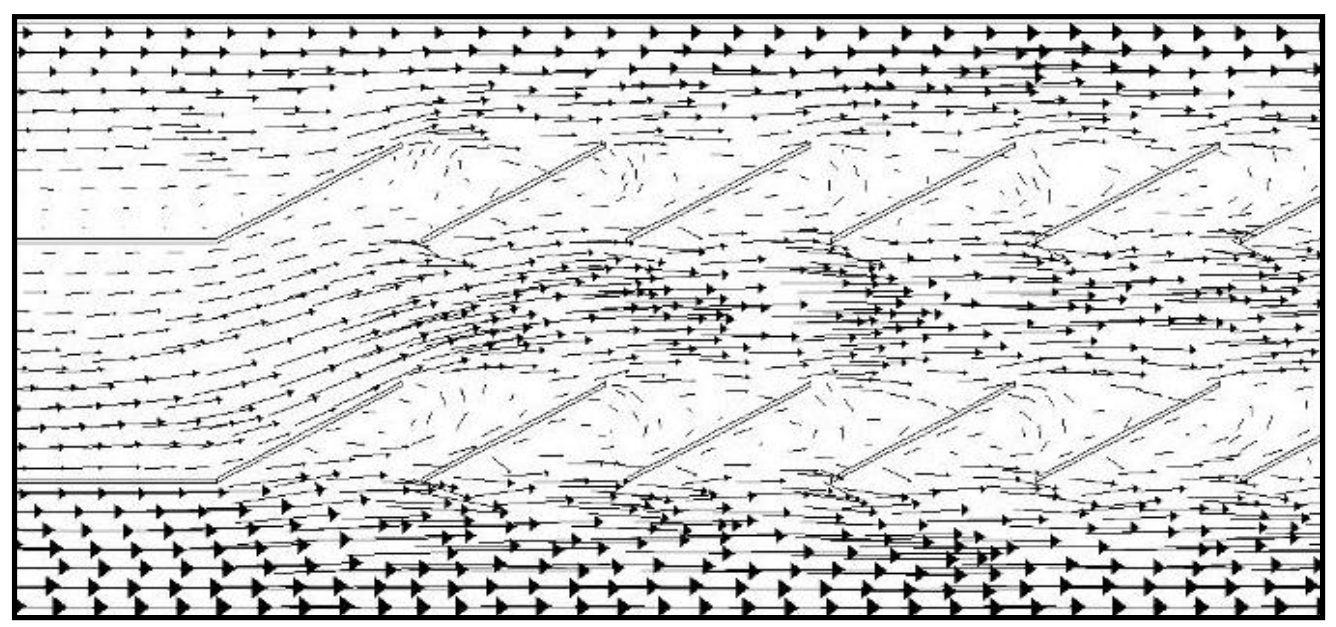

Fig. 19 Vector plot of velocity magnitude of air for the CFD model at air velocity 8 $\mathrm{m} / \mathrm{s}$

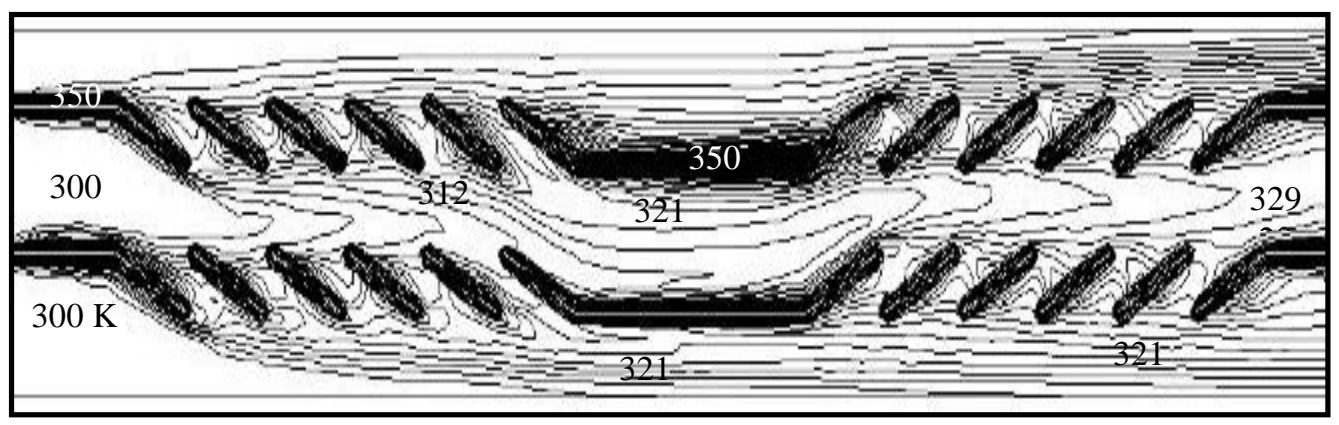

Fig. 20 Temperature contours of air for the CFD model at air velocity $8 \mathrm{~m} / \mathrm{s}$

\section{CONCLUSION}

An automotive radiator performance using flat-tube louvered-fin heat exchanger has been extensively studied, experimentally and numerically, with reference to the flattube flat-fin radiator. The experimental work was carried out on a four cylinders petrol engine. The effects of engine speed, number of fins per inch (FPI), Reynolds number and radiator boundary conditions on the radiator performance are investigated at a certain louvered angle. Numerical CFD investigation using finite volume discretization method was also conducted to predict the radiator performance extensively. The major conclusions from the present investigations are as follows: 
1. At a certain engine speed, the heat transfer coefficient and cooling rate increase with the increase in number of louvered fin per inch. Louvered fins reduce the average thermal boundary-layer thickness by interrupting its growth and increasing turbulence, hence increasing the average heat transfer coefficient.

2. The friction factor decreases with the increase in the Reynolds number. The friction factor across the radiator using flat fin is lower than that across the radiator using louvered-fin.

3. A decrease of about $19 \%$ in the specific fuel consumption at full load in the engine could be achieved due to using louvered-fin compared to the case of radiator using flat fine at the same operating conditions.

4. An improvement of about $23 \%$ in the Nusselt number could be achieved due to using louvered-fin compared to the case of radiator using flat fine with 10 FPI at the same operating conditions.

5. It is noticed that a fair agreement existed between the present numerical and experimental results. The proposed CFD FLUENT-6.2-code model can be employed to simulate other configurations rather than those presented in the present work.

\section{REFERENCES}

[1] F.N. Beauvais, An Aerodynamic Look at Automobile radiators, SAE paper no. 650470, 1965.

[2] C.J. Davenport, Heat Transfer and Fluid Flow in Louvered Triangular Ducts, Ph.D. Thesis, CNAA, Lanchester Polytechnic, 1980.

[3] C. Line, J.Saunders, S.Watkins, The effect of changes in ambient and coolant radiator inlet temperatures and coolant flow rate on specific dissipation, SAE Technical Paper Series SP- 1456,(1999-01-0129), 1999, pp. 23-33.

[4] J.J. Juger, R.F. Crook, Heat transfer performance of glycol versus ethylene glycol coolant solutions in laboratory testing, SAE Technical Paper Series (200001-0579), 2000, pp. 1-12.

[5] M.Gollin, D.Bjork,Comparative performance of ethylene glycol/water and Propylene Glycol/water coolants in automobile radiators, SAE Technical Paper Series SP-1175, (1996-01-0372), 1996, pp. 115-123.

[6] J.A. Chen, D.F. Wang, L.Z. Zheng, Experimental study of operating performance of a tube and fin radiator for vehicles, Journal of Automobile Engineering 205 (6), 2001 pp.911-918.

[7] A. Achaichia, T.A. Cowell, Heat transfer and pressure drop characteristics of flat tube and louvered plate fin surfaces, Exp. Therm. Fluid Sci. 1 (1988) 147157.

[8] R.L. Webb, P. Trauger, Flow structure in the louvered fin heat exchanger geometry, Exp. Therm. Fluid Sci. 4 (1991) 205-217.

[9] D.Ganga Charyulu , G.Singh, J.K. Sharma, Performance evaluation of a radiator in a Diesel engine -a case study, Applied Thermal Engineering 19 (6), 1999, pp.625-939. 
[10] C.O. Olsson and B. Sunden , Heat transfer and pressure drop characteristics of ten radiator tubes, International Journal Of Heat Mass Transfer, Volume 39, No.15, 1996, pp. 3211-3220.

[11] X. Zhang and D.K. Tafti, Flow efficiency in multi-louvered fins, International Journal of Heat Mass Transfer, Volume 46, 2003, pp 1737-1750.

[12] D. K.Tafti and J.Cui, Fin-tube junction effects on flow and heat transfer in flat tube Multi-louvered heat exchangers, International Journal of Heat Mass Transfer, vol.46, 2003, pp. 2027-2038.

[13] C. Oliet, A. Oliva, J. Castro, and C.D. Perez-Segarra, Parametric studies on auto- motive radiators, Applied Thermal Engineering 27, 2007, pp. 2033-2043.

[14] K.N. Atkinson, R. Drakulic, M.R. Heikal andT.A. Cowell, Two and Three dimensional numerical models of flow and heat transfer over louvered fin arrays in compact heat exchangers. International Journal of Heat mass Transfer, 1998, pp. 4063-4080.

[15] Y.Yuan, A. Jackson and M.Nelson, CFD simulation of flow and heat transfer in air ways, 2001, SAE Conf 2001-01-1712.

[16] X.Zhang and D.K.Tafti, Classification and effects of thermal wakes on heat transfer in multilouvered fins, 2001, International Journal of Heat massTransfer; 14, pp.2461-2473.

[17] D.K. Tafti , G. Wang and W. Lin, Flow transition in multi-louvered fin array. 2001, International Journal of Heat mass Transfer;43, pp. 901-919.

[18] T.Perrotin and D.Clodic, Thermal hydraulic CFD study in louvered fin and flat tube Heat exchangers, 2004, International Journal of Refrigeration ; 27, pp. 422432.

[19] J.P. Holman, Experimental Methods for Engineers, McGraw-Hill International Edition, Seventh Edition, New York, USA, 2001.

[20] J.P. Holman, Heat transfer, McGraw-Hill International Edition, Ninth Edition, New York, USA, 2002.

[21] BSI, Methods of Measurement of Fluid Flow in Closed Conduits, Part 1, British Standards, BS1402 Section 1.1, 1981.

[22] Wang C. C., Fu W. L. and Chang C. T. Heat transfer and friction characteristics of typical wavy fin and tube heat exchangers. Experimental thermal and fluid science, 14, (2) PP. 174-186, 1997.

[23] V. Gnielinski, New equations for heat and mass transfer in turbulent pipe and channel flow. International Chemical Engineering, Volume 16, 1976, pp. 359368.

[24] W.M. Kays and A.L. London, Compact Heat Exchangers, McGraw-Hill, NewYork, 1984. 


\section{دراسة عملية وعددية لتحديد أداء مشع تبريد (ردياتير) لمحرك سيارة مزود بزعانف مشقوقة}

يقدم هذا البحث دراسة عملية وعددية لتحديد أداء مشع تبريد (ردياتير) لمحرك سيارة بنزين سيات

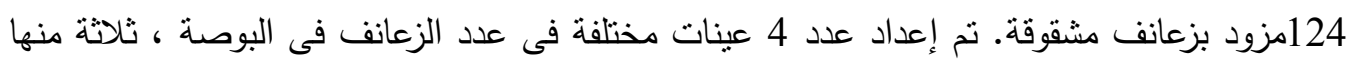
ذو زعانف مشقوقة. وقد نم أختبار العينة الرابعة ذات زعات بعانف مسطحة كمرجعية لهذه العينات. وتم إعداد تختة إختبار معطلية لدراسة تأثثير كل من رقم رينولدز , وسرعة المحرك, والمسافة البينية بين الزعانف وكذلك ظروف التشغيل المختلفة للمحرك على أداء مشع التبريد (الردياتير). ونم أستخدام النموذج الرياضى لدراسة السريان المضطرب بإستخدام K-ع RNG model لتحديد خصائص سريان

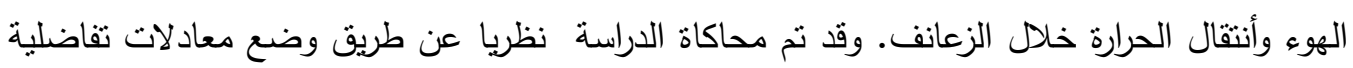

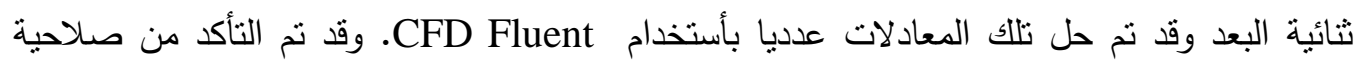

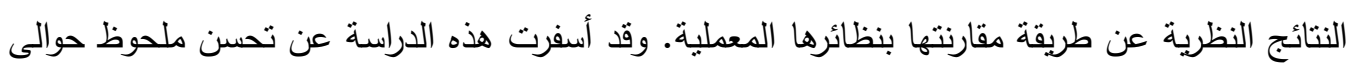
23\% فى خصائص التبريد (رقم نسلت) و أيضا إنخفاض فى معدل أستهلاك الوقود فى المحرك حوالى عنى

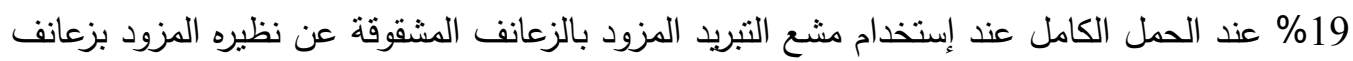
مسطحة عند نفس ظروف التشغيل. 